\title{
Building Beginner Voter's Interest in Political Participation in Indonesia's Election
}

\author{
Zamhasari \\ Department of Governmental Science, Faculty of Social and Political Sciences \\ Universitas Abdurrab \\ Address: Jl. Riau Ujung No. 72 Kota Pekanbaru, Riau, Indonesia 28292 \\ Email: zamhasari@univrab.ac.id
}

\begin{abstract}
The beginner or young voters are considered to play a significant role in the Indonesia's Election. With the competition between candidates running tight, the beginner or young voters can determine the outcome of the election. The age of young voters here is categorized in the range of 17 years to 21 years. These young voters are a connected group of voters so they can be assumed to be critical and unique. Young or beginner voters are eagerly awaiting fresh ideas and programs from candidate pairs related to government. But from the writer's observation that the existence of this beginner voters are still neglected, whereas their existence should be a very promising source of vote in an election. This paper aims to analyze the extent to which beginner voter's interest in political activities in Indonesia. According to Maran (2007) that the main factors that encourage people to participate in politics are: a). Political stimulants, b) Personal characteristics, c) Social characteristics, d) Situation or political environment, e) Political education. The study concludes that there are four issues that young voters are concerned about. Namely, the ease of obtaining alternative jobs that are promised, ease of access to education, ease of access to transportation (mobility), and eradication of corruption.
\end{abstract}

Keywords - Beginner voters; political participation; elections.

\section{INTRODUCTION}

In general, Indonesian citizens are familiar with the General Elections in Indonesia. The implementation of the General Election is a concrete manifestation of commitment of Indonesian Government to guarantee the freedom and sovereignty of the Indonesian people in determining the leaders of this Republic in accordance with the choice of the majority of the people themselves. Indonesia as a democratic nation makes the implementation of this General Election as an instrument for every citizen to determine the representatives of the people starting from the House of Representatives, Provincial Representatives, Regency/City Representatives, even to have the President-Vice President, Governor -Vice Governor, Regents-Vice Regent, and currently included in the Village Head election.

In order to ensure the voter's alignment with political contestants in the election, political contestants, both personally and politically, make every effort to win and win the favor of voters through a series of campaign activities. The results of research Institute of Economic and Public Investigation University of Indonesia (LPEM UI) states that every legislative candidate spend money of Rp. 1.18 billion as a campaign fund, and LPEM UI also mentioned that the average legislative candidate spent Rp. 1.1 billion to be a member of the House of Representatives at 2014.

The writer argues that high voter participation participation in an election contestation is one indicator of success in electoral compliance itself. The writer assumed that the amount of funds spent in each election, where the funds also come from the State Budget and State Expenditures, and we know that one source of the state budget is derived from taxes paid by the people as well. Thus, ideally every fund issued by the people, sourced from the people, should be able to deliver to the common good for the people as well.

Michael Rush and Philip Althoff as quoted by Rafael Raga Maran (2001: 147) political participation is considered as a result of political aspirations. Political participation is an organized effort by citizens to elect their leaders and influence the shape and course of common wisdom. While Miriam Budiardjo (2000: 161) states that "political participation includes all voluntary activities through which a person participates in the process of electing political leaders and participating directly or indirectly in the formation of public wisdom".

A research conducted by Mc's Kinsey Institute (2012) mentions that Indonesia is one of the seven countries with the largest economic growth in the world by 2030, through Germany and Britain, due to the youth population that maintains the economic productivity of Indonesia. It is estimated that $70 \%$ of the Indonesian population is a productive age ranging between 15-64 years in the next 18 years. In the context of politics and elections, it can be interpreted that $70 \%$ of voters in Indonesia are potential voters and if they can be managed properly, it will certainly be a source of votes to win a contest in every election event. Election Commission 2009 has also released data listed in the list of voters remain $20-30 \%$ are beginner voters.

Also, according to the General Elections Commission of the Republic of Indonesia that the voters in Indonesia are divided into three categories namely First, the rational voters ie, the voters who actually vote the party based on assessment and in-depth analysis. Secondly, emotionally critical voters, the electorate who is still idealistic and 
uncompromising. Thirdly, the newly elected voters are the first voters to vote because their age is just entering the voting age.

\section{BEGINNER VOTERS AND TECHNOLOGY}

In the millennium and reform era of Indonesia, the majority of Indonesia's youth and voters are tech-savvy voters. Any form of information can be received in a relatively short time. Therefore, positive information about the political agenda of a party or the political motivation of the contestants is a very important thing to be known to the public before they vote on their political rights. However, according to Burhanuddin Muhtadi, a senior researcher of the Indonesian Survey Institute (LSI), the low political participation rate is due to the fact that political parties do not have clear programs and platforms between one party and another. In the end they only hunt rente, and approach the voters ahead of the election. This ultimately resulted in the electorate being easily rebellious, unfaithful, and subsequently resulting in a fluktualitas support to the parties. Although the election is held, the floating voters still use the right to vote but usually it is because forced. Political apatis continues to rise because they never find a credible alternative party.

In the midst of technological advancements and the rapidity of this information, the neutral role of media in delivering positive news is highly anticipated. Although some of the public already know that behind every mass media there is a group with an interest in it. Khrisna Sen and David T. Hill in his book Media, Culture, and Politics in Indonesia stated that Indonesian mass media is not a role to reflect reality but represent reality. Media in Indonesia easily becomes a tool of power interests to formulate the political, cultural and social reality of Indonesia as thought by the ruling party and not as experienced by the people.

Various forms of social media that existed to make the voters can unite in groups that rhythm and match in accordance with their ideology or views. Not surprisingly, today everyone can create a group in social media in accordance with their own goals and interests. This opportunity can actually be used by political parties and political contestants to campaign their programs while presenting posistif coverage so as to draw attention from public audiences. However, in the midst of easy access to information obtained, not infrequently also found information or news hoax that mutually drop, slander, vilify between one group with another group. In this condition, public intelligence as a voter is expected to be able to sort and distinguish between the true news and false news.

The ability to have $20 \%$ of the voter in Indonesia is actually a source to win election contests. The novice voters whose information is already in their hands, making them a critical and unique voter. Critical because they can like or dislike together in accordance with the ideology or political views that exist in their group, and unique because they can be united in their social media group, where they are in a separate place by distance and time.
One thing that must be understood by these novice voters is the fresh ideas and creative programs of the contestant candidates. The problem is that the faces of the contestants are still dominated by the old face, and only a few new faces. Regeneration in political parties in carrying candidates for political contestants should be an imperative necessity. The effects of the appearance of these old faces certainly also impact on fresh ideas and creative and innovative programs offered by the candidates.

For beginner voters, employment removal programs, easily accessible education by all walks of life, easy and environmentally-friendly public transport and coping strategies of corrupt behavior are still of interest to beginner voters. Political parties and contestants should be able to show their best programs and ideas to meet the expectations of many beginner voters.

\section{POLITICAL CADRE'S AND PARTICIPATION}

Cadres and political education that has not maximized to make party regeneration is also not healthy. The writer sees that being able to engage in a party must have at least some factors: tone, funds, and body luck. A tone or sound that has an attraction that can invite many people to join with his party. The ability to voice and campaign for a party or candidate is something that is needed in the party or a candidate for political contestant who will fight in the general election. That is why political parties or contestant candidates who conduct political campaigns always involve orators, da'is, artists, or other public figures to ensure voters support them.

Not infrequently also found political parties prefer public figures to be represented their party rather than carrying internal party cadres. Thus, it is not surprising that the representatives of the people who fill the seats in parliament are not those who have the competence, quality, commitment, loyalty to their constituents, but those who only have transactional ties alone with the party bearers who are also just pragmatic.

Ownership of funds or property is also one factor to be able to join a party, the political dowry of the term. The ability to pay some money to be promoted to a political contestant is already a public secret. This transactional and pragmatic politics will certainly hinder the emergence of new ideas and program innovations, because it is certain that the main thing done by a winner of political contestation is to get back the amount of funds in accordance with those already issued.

In Indonesia, in practice political parties are still very weak in doing political education. This can be seen from the number of parties that have not conducted political education in a structured, systematic and massive way to its cadres, especially to the common people and beginner voters. When the party approaches the youth and the novice voters, the approach used is still just a mobilization rather than the regeneration. It is unfortunate that until now there are still political parties see the youth and voters beginner as an object to be won rather than the subject to be fostered to jointly build both the party and nation and state. This can be 
seen from the number of political parties that have not done "pick up the ball" to provide education or voter information to young voters and beginners for various reasons. Starting from technical reasons related to budget or a more pragmatic reason.

This has caused not only voter education among young and novice voters to be hampered but also the party oligarchy is getting thickened and the youths become very distant with political activities as well as party activities. A small survey conducted by Perludem with Indocratia, for example, shows that youth in Jakarta alone showed that young people aged 21-23 83\% had no party card and 66\% never attended party events at all (Indocratia, 2013).

Body luck factor is a factor that can be obtained by contestants despite minimal tone and funds, but this is very small to happen. Thus, the sincere contestants to serve and do good to the nation and country can join the political parties that still promote professionalism, quality, and common spirit in advancing this nation and state.

Given the large potential of novice voters in Indonesia who are familiar with information technology, the political participation of newbie voters in elections is expected to increase and the number of political apathy can be minimized. Beginner voters must be aware that such political neglect is a futile form of action against the nation and state. How not, the state has prepared many instruments to ensure that every citizen can channel his vote, but by apathetic citizens, neither instrument is used properly.

The authors argue that if the number of political apathy is still high, then it is better for the general elections organizers to conduct initial data collection to ensure that someone will use his / her right to vote or not exercise his / her right to vote in an election. This I am we should try to be applied in order to minimize the procurement of election instrument which of course can save expenditure and expenditure of state.

Nevertheless, the hope that every citizen can participate maximally remains a top priority for the election organizers. In order to participate in responsible, effective, scientific, electoral activities, several tools of skill in the political process (Budimansyah and Winataputra, 2007: 190) are required. These skills when using the term from Branson (1998: 9) can be categorized as interacting, monitoring and influenting. In relation to the general election, the eligibility of the election may be described as follows:

1. Interacting (interaction) in the election, including:
a. Communicating elections
b. Work together to succeed the election
c. Respond to the election information
d. His position in a conflict

2. Monitoring (supervision) in the election, including:

a. Keep an eye on the election

b. Monitoring election issues

c. Analyze election participants

3. Influenting (influencing) in the election, including:

a. Vote

\section{b. Voice opinion in the election}

According Maran (2007) there are several factors that can stimulate the political participation of society:

1. Political stimulants - Increased political arousal for voters can occur when new ideas and innovation programs offered by political parties and political contestants are logically acceptable to voters, especially novice voters who still have high enthusiasm to see the effects of the votes they contribute in the election. Innovations programs that are continuously voiced and echoed on an ongoing basis can convince voters to stay true to their stance.

2. personal characteristics - Personal characteristics are great capital to win the hearts of voters. In this digital era, positive image of party and personal contestant can be done anytime and from anywhere. But not infrequently the postive imagery collapses instantly and turns into a negative image also caused by the power of the media.

3. Social characteristics - According to Sastroatmodjo (1995: 14-15) the factors that influence the political behavior of a voter are as follows: a) Indirect social and political environment factors such as political system, economic system, cultural system and mass media system. b) The immediate socio-political environmental factors that influence and shape the personality of political actors such as family, religion, school and gay group. This direct social and political environment provides forms of socialization and internalization of community values and norms to political actors and provides life experiences. c) Personality structure factors are reflected in individual sukap. In this factor there are three functional bases of attitude to understand it. The first base is based on the importance of a person's assessment of an object based on one's interests and needs on the object. The second base on the basis of selfadjustment is the judgment that is influenced by the desire to maintain harmony with the subject. The third base is the attitude based on the function of selfexternalization and defense. d) Direct socio-political factors in the form of situations that is, the circumstances that affect the actor directly when will do something activity. These four factors influence the political behavior of political actors either directly or indirectly. One's political behavior is not only based on political considerations but also influenced by non-political considerations.

4. Situation or political environment - According to Ruslan (2000: 101-102) political participation of citizens is strongly influenced by several factors, namely a) religious beliefs believed by individuals, b) Types of political culture, or form of values and beliefs about political activities that influence it, and c) the character of the political environment.

There is also a mention that factors influencing the political participation of newbie voters include: 1) socioeconomic factors, including income level, education level, and number of novice voters, 2) Political factors include, political communication, political awareness, knowledge voters about the political 
process, 3) individual and environmental physical factors, and 4) cultural value factors.

5. Political education - According to Ramlan Surbakti, in giving understanding about political education must be explained first about the socialization of politics. Surbakti (1999: 117) argues that: Political socialization is divided into two, namely political education and political indoctrination. Political education is a process of dialogue between the giver and the recipient of the message. Through this process community members recognize and learn the values, norms and political symbols of their country from various parties in political systems such as schools, government and political parties.

The objectives of the political education activities in novice voters, among others; 1) Building awareness and critical thinking of young voters to elect and participate in holding clean and anti-political elections through political education, 2) Provide information related to the procedure of choosing, 3) Unlocks beginner voters' insights on various election issues such as e-government, the role of social media in politics and elections, electoral offenses, and permanent voter lists.

The important role of political education to beginner voters is to realize the life of democratic society, namely as citizens who think critically, and act democratically through the activities of inculcate to novice voters on three things, among them first, democracy is the most secure form of social life the rights of the citizen of society itself. Secondly, democracy is a learning process that can not simply imitate from other societies. Third, the continuity of democracy depends on the success of transforming democratic values: freedom, equality and justice and loyal to a democratic political system (Zamroni, 2001: 17).

\section{CONCLUSION}

As a beginner voter who still holds strong idealism for a progressive Indonesia, the turn of political leaders in Indonesia is expected to bring positive change and better progress from the previous leadership period. Beginner voters hope that leadership changes can create and open new jobs. The dream to improve the level of prosperity, especially in the economic field is one of them. Improvement of education with all its aspects also did not escape the expectations of many beginner voters. They realize that one way to improve the condition of this nation is through quality education. Beginner voters also consider that the ease of transportation access and crackdown on all forms of corruption is still the hope of this nation's children.

\section{References}

[1] Branson, M.S. 1998. The Role of Civic Education. Calabasas : CCE

[2] Budiarjo, Miriam. 2000. Dasar-dasar Ilmu Politik. Jakarta: Gramedia Pustaka Utama.

[3] Budimansyah \& Winataputra. 2007. Civic Education Konteks, Landasan Bahan Ajar dan Kultur Kelas. Bandung : Program Studi Pendidikan Kewarganegaraan SPS UPI
[4] H usein Harun, Pemilu Indonesia (Fakta, Angka, Analisis, dan Studi Banding), (Jakarta: Perkumpulan Untuk Pemilu dan Demokrasi), hlm. 303.

[5] Indocratia. Presentasi: Survey Pemuda 2013, (makalah tidak diterbitkan), hlm. 13.

[6] Khrisna Sen dan David T.Hill, Media, Culture, and Politics In Indonesia, (London: Oxford University Press, 2000), hlm. 125.

[7] Komisi Pemilihan Umum, 2014, Kaum Marginal Cerdas Berdemokrasi, Jakarta: Komisi Pemilihan Umum. http://kpu.go.id/dmdocuments/modul_1d.pdf

[8] Komisi Pemilihan Umum, Buku Saku Pemilu 2009: Hasil Pemilu Anggota DPR, DPD dan DPRD (Jakarta: Komisi Pemilihan Umum, 2009), hlm. 41

[9] Maran, Rafael Raga. 2001. Pengantar Sosiologi Politik. Jakarta: PT. Rineka Cipta

[10] Mc. Kinsey Global Institute, The Archipelago Economy: Unleashing Indonesia Potentials, (Mc.Kinsey \& Company, 2012), hlm. 15

[11] Ruslan, Ustman Abdul Muiz. 2000. Pendidikan Politik Ikhwanul Muslimin. Solo: Era Intermedia.

[12] Sastroatmodjo, Sudijono. 1995. Perilaku Politik. Semarang: IKIP Semarang Press.

[13] Surbakti, Ramlan. (1999). Memahami Ilmu Polilik. Jakarta: PT Gramedia Widiasarana Indonesia.

[14] Zamroni, (2000), Pendidikan Tantangan Menuju untuk Demokrasi (Civil Society). Jakarta: Bigraf Publishing. 